\title{
Pengaruh Penggunaan Rumput Laut dalam Pellet Pakan Kelinci terhadap Tingkat Kekerasan, Durabilitas dan Organoleptik Pellet
}

\section{Effect of the Use of Seaweed in Rabbit Feed Pellet on the Level of Hardness, Durability and Organoleptic Pellet}

\author{
A. R. Majiid, S. Mukodiningsih, dan S. Sumarsih \\ Fakultas Peternakan dan Pertanian, Universitas Diponegoro, Semarang \\ Jl. Prof. H. Soedarto, S. H. -Tembalang, Semarang, Indonesia - 50275 \\ Corresponding e-mail: achmadriza1300797@gmail.com
}

\begin{abstract}
The research aims to examine the effect of the use of seaweed in rabbit feed pellets on the level of hardness, durability and organoleptic pellets. The materials used are Sargassum sp. Flour, yellow corn flour, pollard, soybean meal, wheat brand, rice bran, coffee husk, coconut cake, molasses, minerals and salt. The study used a completely randomized design (CRD) with 3 treatments namely $\mathrm{T} 0=$ feed with Sargassum sp. $0 \%$, T1 $=$ feed with Sargassum sp. 4\% and T2 = feed with Sargassum sp. $8 \%$ and 6 replications. The parameters observed were level of hardness, durability, color, texture and pellet aroma. Data analysis used analysis of variance at the 5\% level and continued with duncan double region test. The results showed that the use of Sargassum sp. significant effect $(\mathrm{P}<0.05)$ reduced the hardness, color, texture, and aroma scores, but did not significantly affect the durability of rabbit feed pellets. The average hardness of treatments T0, T1 and T2 are 13.50; 12,13 and 11,17 $\mathrm{kg}$, the average durability of the treatments T0, T1 and T2 are 94.88; 95.13 and $95.38 \%$, the average color score of the treatments T0, T2, and T1 are $4.00 ; 3.01 ; 3.00$, the average texture scores of treatments T0, T1 and T2 are $2.88 ; 2.83 ; 2.20$ and the average aroma score of the treatments $\mathrm{T} 0, \mathrm{~T} 1$ and $\mathrm{T} 2$ are $4.00 ; 3.69$; and 3.64. The conclusion of the research are the use of Sargassum sp. up to $8 \%$ can reduce the level of pellet hardness, the value of pellet durability is good, the color is blackish brown, the texture of the pellet is getting rough and the aroma of pellet is rather fishy.
\end{abstract}

Key words : durability, hardness, organoleptic, Sargassum sp

\begin{abstract}
ABSTRAK
Penelitian bertujuan untuk mengkaji pengaruh penggunaan rumput laut dalam pellet pakan kelinci terhadap tingkat kekerasan, durabilitas dan organoleptik pellet. Materi yang digunakan adalah tepung Sargassum sp., tepung jagung kuning, pollard, bungkil kedelai, wheat brand, bekatul, kulit kopi, bungkil kelapa, molasses, mineral dan garam. Penelitian menggunakan rancangan acak lengkap (RAL) dengan 3 perlakuan yaitu T0= pakan dengan level Sargassum sp. 0\%, T1 = pakan dengan level Sargassum sp. 4\% dan T2 = pakan dengan level Sargassum sp. 8\% dan 6 ulangan. Parameter yang diamati yaitu tingkat kekerasan, durabilitas, warna, tekstur dan aroma pellet. Analsis data menggunakan analisis ragam pada taraf 5\% dan dilanjutkan dengan uji wilayah ganda duncan. Hasil menunjukkan bahwa penggunaan level Sargassum sp. berpengaruh nyata $(\mathrm{P}<0,05)$ menurunkan skor hardness, warna, tekstur, dan aroma, tetapi tidak berpengaruh nyata terhadap durabilitas pellet pakan kelinci. Rataan hardness perlakuan T0, T1 dan T2 yaitu 13,50; 12,13 dan 11,17 kg, rataan durabilitas perlakuan T0, T1 dan T2 yaitu 94,88; 95,13 dan 95,38\%, rataan skor warna perlakuan T0, T2, dan T1 yaitu 4,00; 3,01; 3,00 , rataan skor tekstur perlakuan T0, T1 dan $\mathrm{T} 2$ yaitu 2,88; 2,83; 2,20 dan rataan skor aroma perlakuan T0, T1 dan T2 yaitu 4,00; 3,69; dan 3,64. Simpulan penelitian adalah penggunaan level Sargassum sp. hingga 8\% dapat menurunkan tingkat kekerasan pellet, nilai durabilitas pellet yang baik, warna coklat kehitaman, tekstur pellet semakin kasar dan aroma pellet agak berbau amis.
\end{abstract}

Kata kunci : durabilitas, hardness, organoleptik, Sargassum sp.

\section{PENDAHULUAN}

Pakan merupakan salah satu unsur penting dalam perkembangan suatu usaha peternakan. Kualitas pakan yang baik akan menghasilkan produktivitas ternak yang baik yang salah satunya dapat ditingkatkan dengan cara pengolahan pakan dalam bentuk pellet. Pellet merupakan modifikasi pakan dari bentuk mash yang dihasilkan dari pengepresan mesin pellet menjadi lebih keras (Retnani et al., 2010).

Pemberian pakan pellet pada kelinci akan mengurangi pengambilan pakan secara selektif 
dan dapat mengurangi pakan yang tercecer. Kelinci pada masa pertumbuhan membutuhkan serat kasar sebesar 10-12\%, Digestible Energy (DE) $2500 \mathrm{kkal} / \mathrm{kg}$, protein kasar 16\% dan lemak kasar 2\% (Nutrient Requirements of Rabbits, 1977). Kelinci merupakan jenis ternak herbivora sekaligus pseudoruminant yang mempunyai kemampuan untuk mencerna serat kasar secara terbatas hal ini dikarenakan kelinci memiliki sifat coprophage yaitu memakan kembali fesesnya dan memiliki sistem pencernaan yang sederhana yaitu caecum dan usus besar yang digunakan untuk mencerna hijauan, rumput dan sejenisnya, akan tetapi kelinci juga membutuhkan kandungan serat kasar dalam pakan agar kebutuhan serat kasar dalam tubuh kelinci tercukupi (Satriawan et al., 2017). Bahan pakan alternatif untuk memenuhi kebutuhan serat kasar bagi kelinci salah satunya adalah rumput laut Sargassum $s p$.

Rumput laut jenis Sargassum sp. merupakan salah satu sumber daya alam yang tersedia melimpah di perairan Indonesia, hal ini dikarenakan rumput laut Sargassum sp. belum banyak dimanfaatkan oleh manusia dan berpeluang untuk dijadikan sebagai pakan serta masih tumbuh secara liar. Menurut Luthfiyana et al. (2016) menyatakan bahwa produksi rumput laut jenis Sargassum sp. mencapai 482.400 ton per tahun. Rumput laut Sargasssum sp. atau alga coklat mengandung pati polisakarida berupa amilosa, amilopektin serta selulosa yang tidak larut dalam air. Selulosa dari rumput laut dapat dikonversi menjadi glukosa dengan teknik sakarifikasi. Polisakarida merupakan salah satu penyusun karbohidrat yang memiliki keterkaitan dengan serat suatu bahan, oleh karena itu tingginya serat dapat disebabkan oleh tingginya polisakarida pada sel rumput laut (Ma'ruf et al., 2013). Menurut Rachmayanti et al. (2019) kandungan nutrisi pada rumput laut jenis Sargassum sp. memiliki kadar karbohidrat $19,06 \%$, protein $5,53 \%$, lemak $0,74 \%$, air $11,71 \%$, abu $24,57 \%$, serat kasar $28,39 \%$ dan mengandung polisakarida berupa selulosa berkisar 23,97-35,22\%.

Pati merupakan karbohidrat yang terdiri dari amilosa dan amilopektin, amilosa memberikan sifat keras sedangkan amilopektin menyebabkan sifat lengket (Herawati, 2011). Penggunaan pati yang terkandung di dalam rumput laut Sargassum sp. berhubungan dengan tingkat kekerasan dan durabilitas pellet karena pati dapat dijadikan sebagai bahan baku untuk mengikat komponen beberapa bahan pakan agar pellet yang dihasilkan kokoh dan kompak, selain itu serat dalam rumput laut ini berhubungan dengan tekstur dan kekompakan pellet karena semakin besar serat maka tekstur pakan semakin kasar dan juga fungsi serat sebagai pembentuk ikatan antar partikel. Sargassum sp. memiliki zat warna coklat yang akan berdampak pada warna pellet serta habitat dari Sargassum sp. yang berasal dari laut ini akan berpengaruh pada aroma pellet dan jika pemberian level Sargassum sp. semakin besar maka akan berdampak pada warna dan aroma pellet.

Komponen penyusun bahan baku untuk pellet mempengaruhi kualitas fisik pellet terutama kandungan pati yang bertindak sebagai pengikat dan perubahan selama proses mekanik dapat meningkatkan gelatinisasi pati, serat kasar bertindak sebagai pembentuk ikatan antar partikel, serat yang tidak laut air dapat berpengaruh terhadap ketahanan dan jika komposisinya besar akan terjadi fragmentasi yang mengakibatkan penurunan kualitas fisik pellet, lignin untuk membantu proses pengikatan pellet jika suhu tinggi dan lemak bertindak sebagai pelumas, gesekan dan tekanan dalam pencetak (Ilmiawan et al., 2015). Penggunaan bahan baku untuk pellet yang baik akan menghasilkan pellet dengan kualitas yang baik yang dapat dilihat dari tingkat kekerasan, durabilitas dan organoleptiknya. Penggunaan Sargassum sp. dan pengaruhnya terhadap kualitas fisik dan organoleptik pellet pakan kelinci belum pernah dikaji.

Penelitian ini bertujuan untuk mengkaji pengaruh penggunaan rumput laut Sargassum sp. dalam pellet pakan kelinci terhadap tingkat kekerasan, durabilitas dan organoleptik pellet. Manfaat dari penelitian ini adalah dapat memberikan informasi mengenai pengaruh rumput laut Sargassum $s p$. terhadap tingkat kekerasan, durabilitas dan organoleptik pellet.

\section{MATERI DAN METODE}

Materi penelitian antara lain tepung Sargassum sp., tepung jagung kuning, pollard, bungkil kedelai, wheat brand, bekatul, kulit kopi, bungkil kelapa, molasses, mineral dan garam. Peralatan penelitian antara lain mesin pellet vertikal, baskom, mangkok plastik, timbangan digital merk "Camry" kapasitas $5 \mathrm{~kg}$ dengan ketelitian $1 \mathrm{~g}$, hardness tester manual, durability tester, mesin grinder, ember serta kuesioner.

Penelitian dilakukan menggunakan rancangan acak lengkap (RAL) dengan 3 
perlakuan dan 6 ulangan. Perlakuan yang diberikan yaitu :

T0 = Pakan dengan level Sargassum sp. $0 \%$.

$\mathrm{T} 1=$ Pakan dengan level Sargassum sp. 4\%

$\mathrm{T} 2=$ Pakan dengan level Sargassum sp. $8 \%$

Penelitian dilaksanakan dengan tiga tahap mulai dari persiapan, pembuatan pellet dan pengambilan data. Tahap persiapan penelitian meliputi pencarian Sargassum $s p$. di pantai Bandengan Jepara, pengeringan Sargassum sp. dibawah matahari dan penggilingan dengan menggunakan grinder, persiapan peralatan, pembelian bahan pakan, analisis proksimat masing-masing bahan pakan (Tabel 1) dan penyusunan pakan kelinci (Tabel 2). Pengambilan data untuk pengujian kualitas fisik pellet meliputi tingkat kekerasan dan durabilitas pellet menurut metode (Ilmiawan et al., 2015) . Data yang diambil untuk pengujian organoleptik pellet antara lain warna, tekstur dan aroma menurut metode (Fathia, 2016). Nilai durabilitas pellet dapat dihitung dengan rumus:

Durabilitas $=\frac{\text { berat sisa pellet }}{\text { berat pellet awal }} \times 100 \%$

(Ismi et al., 2017).
Tabel 2. Formulasi pakan kelinci

\begin{tabular}{|c|c|c|c|}
\hline \multirow[t]{2}{*}{ Bahan Pakan } & \multicolumn{3}{|c|}{$\begin{array}{l}\text { Komposisi Formulasi Pakan } \\
\text { Kelinci }\end{array}$} \\
\hline & T0 & $\mathrm{T} 1$ & $\mathrm{~T} 2$ \\
\hline & \multicolumn{3}{|c|}{-----------------\%o------------- } \\
\hline Jagung kuning & 8 & 7,7 & 7,4 \\
\hline Pollard & 13 & 12,5 & 12 \\
\hline Bungkil kedelai & 9 & 8,6 & 8,3 \\
\hline Wheat brand & 38 & 36,5 & 35 \\
\hline Bekatul & 13 & 12,5 & 12 \\
\hline Kulit kopi & 8 & 7,7 & 7,4 \\
\hline Bungkil kelapa & 10 & 9,6 & 9,2 \\
\hline Molasses & 0,2 & 0,2 & 0,2 \\
\hline Mineral & 0,4 & 0,4 & 0,4 \\
\hline Garam & 0,4 & 0,4 & 0,4 \\
\hline Rumput laut & 0 & 4 & 8 \\
\hline Total & 100 & 100 & 100 \\
\hline \multicolumn{4}{|l|}{ Nutrisi } \\
\hline Protein kasar (\%) & 15,17 & 14,75 & 14,93 \\
\hline Lemak kasar (\%) & 4,44 & 4,48 & 5,10 \\
\hline Serat kasar (\%) & 15,24 & 17,49 & 17,70 \\
\hline Digestible & 2950,73 & 2859,99 & 2824,44 \\
\hline $\begin{array}{l}\text { Energy }(\mathrm{kkal} / \mathrm{kg}) \\
\text { Abu }(\%)\end{array}$ & 6,06 & 6,66 & 7,64 \\
\hline
\end{tabular}

Prosedur pengujian organoleptik yang dilakukan yaitu warna, tekstur dan aroma pellet yang dilakukan dengan bantuan 20 orang panelis agak terlatih untuk membandingkan warna, tekstur dan aroma pellet (Tabel 3).

Tabel 1. Kandungan nutrisi bahan pakan (dalam 100\% BK)

\begin{tabular}{lccccccc}
\hline \multicolumn{1}{c}{ Bahan Pakan } & $\begin{array}{c}\text { Bahan } \\
\text { Kering } \\
(\%)\end{array}$ & $\begin{array}{c}\text { Protein } \\
\text { Kasar } \\
(\%)\end{array}$ & $\begin{array}{c}\text { Lemak } \\
\text { Kasar } \\
(\%)\end{array}$ & $\begin{array}{c}\text { Serat } \\
\text { Kasar } \\
(\%)\end{array}$ & $\begin{array}{c}\text { BETN } \\
(\%)\end{array}$ & $\begin{array}{c}\text { Abu } \\
(\%)\end{array}$ & DE (kkal/kg) \\
\hline Jagung Kuning & 88,91 & 8,95 & 3,64 & 8,98 & 76,98 & 1,45 & 3750,87 \\
Pollard & 88,37 & 14,40 & 4,13 & 6,34 & 71,91 & 3,22 & 3581,34 \\
Bungkil Kedelai & 89,60 & 45,44 & 2,97 & 9,42 & 35,20 & 6,97 & 2939,44 \\
Rumput Laut & 87,20 & 6,74 & 1,76 & 21,40 & 49,51 & 20,59 & 582,164 \\
Wheat Brand & 87,47 & 14,70 & 1,82 & 19,66 & 59,00 & 4,82 & 2916,07 \\
Bekatul & 87,38 & 12,37 & 18,09 & 15,74 & 45,35 & 8,45 & 2519,69 \\
Kulit Kopi & 87,92 & 11,89 & 1,02 & 22,54 & 56,62 & 7,93 & 2373,10 \\
Molasses & 67,50 & 2,42 & 0,90 & 0,96 & 83,82 & 11,9 & 2503,34 \\
Bungkil Kelapa & 88,06 & 18,27 & 10,25 & 15,32 & 50,25 & 5,91 & 2900,16 \\
\hline
\end{tabular}

Sumber : Hasil Analisis Laboratorium Ilmu Nutrisi dan Pakan Universitas Diponegoro, 2018.

Keterangan : BETN = Bahan Ekstrak Tanpa Nitrogen; $\quad D E=$ Digestible Energy Rumus DE $=4253-32,6(\% \mathrm{SK})-144,4(\% \mathrm{Abu})$ (Molina et al., 2015). 
Tabel 3. Penilaian kualitas organoleptik pellet pakan kelinci

\begin{tabular}{llc}
\hline & \multicolumn{1}{c}{ Kriteria } & Skor \\
\hline Warna & & \\
& Coklat Cerah & 4 \\
& Coklat Kehitaman & 3 \\
& Coklat Kehitaman Kusam & 2 \\
& Kusam mendekati abu-abu & 1 \\
\hline Tekstur & & \\
& Sangat Halus & 4 \\
& Halus & 3 \\
& Kasar & 2 \\
& Sangat Kasar & 1 \\
\hline Aroma & & \\
& Segar & 3 \\
& Agak Amis & 3 \\
& Amis & 2 \\
& Sangat Amis & 1 \\
\hline
\end{tabular}

*Semakin rendah skor pellet maka kualitas pellet pakan kelinci semakin rendah.

Analisis data menggunakan analisis ragam (Analysis of Variance) pada taraf signifikasi $5 \%$ untuk mengetahui pengaruh nyata atau tidaknya perlakuan terhadap parameter. Uji Jarak Berganda Duncan dilakukan jika diperoleh pengaruh yang nyata pada taraf signifikasi 5\% untuk mengetahui ada atau tidaknya perbedaan antar perlakuan dari masing-masing parameter (Mas, 2015).

\section{HASIL DAN PEMBAHASAN}

Tabel 4. Rataan nilai hardness dan durabilitas pellet pakan kelinci dengan level Sargassum $s p$. yang berbeda

\begin{tabular}{ccc}
\hline \multirow{2}{*}{ Perlakuan } & \multicolumn{2}{c}{ Parameter } \\
\cline { 2 - 3 } & $\begin{array}{c}\text { Hardness } \\
(\mathrm{kg})\end{array}$ & $\begin{array}{c}\text { Durabilitas } \\
(\%)\end{array}$ \\
\hline T0 & $13,50^{\mathrm{a}}$ & 94,88 \\
T1 & $12,13^{\mathrm{b}}$ & 95,13 \\
T2 & $11,17^{\mathrm{b}}$ & 95,38 \\
\hline
\end{tabular}

Keterangan : Supersrip yang berbeda pada kolom yang sama menunjukkan perbedaan nyata $(\mathrm{P}, 0,05)$

\section{Pengaruh Penggunaan Rumput Laut dalam Pellet Pakan Kelinci terhadap Tingkat Kekerasan Pellet}

Berdasarkan Tabel 4. Rataan hardness (kekerasan) pellet pakan kelinci perlakuan T0, T1 dan T2 berturut-turut adalah 13,50;12,13 dan $11,17 \mathrm{~kg}$. Hasil analisis ragam menunjukkan bahwa adanya penambahan level rumput laut Sargassum sp. dalam pakan kelinci berpengaruh nyata $(\mathrm{P}<0,05)$ menurunkan tingkat kekerasan pellet pakan kelinci. Uji lanjut wilayah ganda Duncan menunjukkan bahwa perlakuan T0 berbeda nyata $(\mathrm{P}<0,05)$ lebih tinggi dari perlakuan T1 dan T2. Perlakuan T1 tidak berbeda nyata lebih tinggi dari perlakuan $\mathrm{T} 2$ dan berbeda nyata $(\mathrm{P}<0,05)$ lebih rendah dari perlakuan $\mathrm{T} 0$. Perlakuan T2 tidak berbeda nyata lebih rendah dari perlakuan $\mathrm{T} 1$ dan berbeda nyata $(\mathrm{P}<0,05)$ lebih rendah dari perlakuan T0.

Penurunan tingkat kekerasan pada pellet terjadi karena kandungan zat nutrisi serat yang terkandung dalam pellet semakin tinggi baik dari serat Sargassum sp., kulit kopi maupun bahan pakan yang memiliki sumber serat yang tinggi sehingga kekerasan pellet dapat berkurang. Menurut (Ilmiawan et al., 2015) semakin besar komposisi serat dalam pellet akan menurunkan ikatan antar partikel dan akan terjadi fragmentasi sehingga menurunkan kekerasan pada pellet. Pellet kelinci ini memiliki panjang 2-3 cm dengan diameter $0,4 \mathrm{~cm}$ akan tetapi semua perlakuan pellet menunjukkan tingkat kekerasan pellet yang melebihi standar. Menurut Mukodiningsih et al. (2010) menyatakan bahwa tingkat kekerasan pellet yang baik dengan diameter pellet $4-5 \mathrm{~mm}$ adalah $4 \mathrm{~kg} / \mathrm{cm}^{2}$, sedangkan diameter $6-8 \mathrm{~mm}$ adalah $6,5 \mathrm{~kg} / \mathrm{cm}^{2}$. Tingkat kekerasan yang melebihi standar terjadi karena kondisi bahan pakan yang sudah halus sebelum proses pencetakan pellet dan penggunaan binder berupa molasses sehingga kekerasan pellet akan meningkat. Campuran bahan pakan yang halus dapat meningkatkan kekerasan pellet karena ikatan antar partikel yang dipengaruhi oleh proses penekanan bahan pada saat pembuatan pellet akan semakin kuat sehingga diperoleh pellet dengan kekerasan yang tinggi (Mulia et al., 2017). Menurut Ismi et al. (2017) menyatakan bahwa penggunaan binder berupa molasses mampu meningkatkan kekerasan pellet. Hasil menunjukkan bahwa perlakuan terbaik untuk tingkat kekerasan pellet yaitu pada perlakuan T2 karena paling mendekati nilai standar kekerasan pellet.

\section{Pengaruh Penggunaan Rumput Laut dalam Pellet Pakan Kelinci terhadap Durabilitas Pellet}

Berdasarkan Tabel 4. Rataan durabilitas pellet pakan kelinci perlakuan T0, T1 dan T2 berturut-turut adalah 94,88; 95,13 dan 95,38\%. Hasil analisis ragam menunjukkan bahwa penambahan level rumput laut Sargassum sp. hingga $8 \%$ dalam pakan kelinci tidak 
berpengaruh nyata terhadap kualitas durabilitas pellet pakan kelinci. Menurut Mukodiningsih et al. (2010) menyatakan bahwa nilai durabilitas pellet yang baik dengan diameter pellet 4-8 $\mathrm{mm}$ lebih dari $90 \%$ lebih tepatnya yaitu $96 \%$. Tingginya nilai durabilitas pada masing-masing perlakuan terjadi karena perekat alami berupa pati yang terkandung dalam pakan mampu mengikat semua bahan pakan dengan baik dan menghasilkan pellet pakan kelinci yang kompak dan kokoh. Menurut Susilawati et al. (2012) menyatakan bahwa bahan pengikat yang mengandung pati dalam proses pembuatan pellet diantaranya dapat berupa jagung, tepung ubi kayu, tepung beras, pollard, molasses dan bahanbahan lainnya yang tinggi kandungan patinya. Nilai durabilitas pada pellet menunjukkan hasil yang tinggi juga dikarenakan Sargassum $s p$. mengandung pati polisakarida berupa amilosa dan amilopektin sehingga mampu meningkatkan perekatan antar partikel pakan menjadi lebih kompak dan kokoh dalam mempertahankan kondisinya. Menurut Triwisari (2010) Sargassum $s p$. atau dikenal sebagai alga coklat ini memiliki kandungan pati polisakarida berupa amilosa dan amilopektin, selain itu memiliki polisakarida lainnya berupa pati namun jumlahnya kecil.

Nilai durabilitas pada pellet menggambarkan banyaknya pellet yang mampu bertahan terhadap benturan, gesekan, guncangan pada saat proses penyimpanan maupun distribusi (Krisnan dan Ginting, 2009). Faktor yang mempengaruhi nilai durabilitas pada pellet antara lain karakteristik bahan baku (protein, lemak, serat, pati), kepadatan, tekstur, air dan kestabilan karakteristik bahan (Rahmana et al., 2016). Hasil menunjukkan bahwa perlakuan terbaik untuk durabilitas pellet yaitu pada perlakuan T2 yaitu 95,38\% karena paling mendekati nilai standar.

Tabel 5. Rataan nilai warna, tekstur dan aroma pellet pakan kelinci dengan level Sargassum $s p$. yang berbeda

\begin{tabular}{cccc}
\hline \multirow{2}{*}{ Perlakuan } & \multicolumn{3}{c}{ Parameter } \\
\cline { 2 - 4 } & Warna & Tekstur & Aroma \\
\hline T0 & $4,00^{\mathrm{a}}$ & $2,88^{\mathrm{a}}$ & $4,00^{\mathrm{a}}$ \\
T1 & $3,00^{\mathrm{b}}$ & $2,83^{\mathrm{a}}$ & $3,69^{\mathrm{b}}$ \\
T2 & $3,01^{\mathrm{b}}$ & $2,20^{\mathrm{b}}$ & $3,64^{\mathrm{b}}$ \\
\hline
\end{tabular}

Keterangan : Supersrip yang berbeda pada kolom yang sama menunjukkan perbedaan nyata $(\mathrm{P}, 0,05)$

\section{Pengaruh Penggunaan Rumput Laut dalam} Pellet Pakan Kelinci terhadap Warna Pellet

Berdasarkan Tabel 5. menunjukkan bahwa rataan skor warna pellet pakan kelinci perlakuan T0, T1 dan $\mathrm{T} 2$ berturut-turut adalah 4,$00 ; 3,00$ dan 3,01. Hasil analisis ragam menunjukkan bahwa adanya penambahan level rumput laut Sargassum $s p$. dalam pakan kelinci berpengaruh nyata $(\mathrm{P}<0,05)$ menurunkan skor warna pellet pakan kelinci. Uji wilayah ganda Duncan menunjukkan bahwa perlakuan T0 berbeda nyata $(\mathrm{P}<0,05)$ lebih tinggi dari perlakuan T1 dan T2. Perlakuan T1 berbeda nyata $(\mathrm{P}<0,05)$ lebih rendah dari perlakuan $\mathrm{T} 0$ dan tidak berbeda nyata dari perlakuan T2. Perlakuan T2 berbeda nyata $(\mathrm{P}<0,05)$ lebih rendah dari perlakuan $\mathrm{T} 0$ dan tidak berbeda nyata dari perlakuan $\mathrm{T} 1$.

Perubahan warna dari coklat cerah menjadi coklat kehitaman terjadi karena warna bahan pakan rumput laut Sargassum sp. yang dikeringkan dibawah sinar matahari hingga kering berwarna hitam. Semakin banyak level rumput laut Sargassum sp. dalam pakan kelinci maka warna hitam akan mendominasi dari warna bahan pakan yang lainnya. Menurut Ismi et al. (2017) menyatakan bahwa warna pellet yang baik adalah pellet yang berwarna sesuai dengan bahan penyusunnya dan tidak akan berpengaruh pada palatabilitas ternak. Ruslan dan Wiraningtyas (2019) menyatakan bahwa Sargasssum sp. mengandung zat warna antara lain fukosantin, klorofil, karoten akan tetapi fikosantin sangat dominan yang memberikan warna coklat tua. Hasil menunjukkan bahwa pellet yang sesuai standar yaitu pada perlakuan T0 yaitu skor 4 kategori warna coklat cerah. Menurut Harianto et al. (2016) menyatakan bahwa pakan pellet yang baik memiliki bau khas sesuai dengan bahan penyusunnya, berwarna coklat, bertekstur halus serta tidak ditumbuhi jamur. Hasil menunjukkan bahwa perlakuan terbaik untuk warna pellet yaitu pada perlakuan T0 karena sudah sesuai dengan standar warna pellet.

\section{Pengaruh Penggunaan Rumput Laut dalam Pellet Pakan Kelinci terhadap Tekstur Pellet}

Berdasarkan Tabel 5. menunjukkan bahwa rataan skor tekstur pellet pakan kelinci perlakuan T0, T1 dan T2 berturut-turut adalah 2,$88 ; 2,83$ dan 2,20 termasuk dalam kategori kasar. Hasil analisis ragam menunjukkan bahwa adanya penambahan level rumput laut Sargassum $s p$. dalam pakan kelinci berpengaruh nyata $(\mathrm{P}<0,05)$ menurunkan skor tekstur pellet pakan kelinci. Uji wilayah ganda Duncan menunjukkan bahwa perlakuan $\mathrm{T} 0$ berbeda nyata $(\mathrm{P}<0,05)$ lebih tinggi dari perlakuan $\mathrm{T} 2$ dan tidak berbeda nyata dengan perlakuan T1. Perlakuan T1 
berbeda nyata $(\mathrm{P}<0,05)$ lebih tinggi dari perlakuan T2 dan tidak berbeda nyata lebih rendah dengan perlakuan T0. Perlakuan T2 berbeda nyata $(\mathrm{P}<0,05)$ lebih rendah dari perlakuan T0 dan T1.

Penurunan skor tekstur pellet menjadi kasar terjadi karena kandungan serat kasar yang terkandung dalam pakan semakin banyak yaitu dari Sargassum sp. yang tinggi kadar seratnya sehingga membuat tekstur pellet menjadi berongga. Aslamyah dan Karim (2012) menyatakan bahwa tekstur pakan pellet dapat dilihat dari permukaannya, selain itu jumlah serat dan berlubangnya pakan tersebut. Hasil menunjukkan bahwa tekstur pellet masih belum memenuhi standar pellet yang baik. Menurut Harianto et al. (2016) menyatakan bahwa standart pellet yang baik yaitu memiliki tekstur lembut dan halus serta tidak ditumbuhi oleh jamur. Ismi et al. (2017) menyatakan bahwa perubahan kualitas tekstur pellet menjadi semakin kasar terjadi karena kandungan serat kasar pakan tinggi dan terjadi pengurangan pada bahan perekat pakan. Hasil menunjukkan bahwa perlakuan terbaik untuk tekstur pellet yaitu pada perlakuan T0 yaitu 2,88 karena paling mendekati nilai standar tekstur pellet.

\section{Pengaruh Penggunaan Rumput Laut dalam Pellet Pakan Kelinci terhadap Aroma Pellet}

Berdasarkan Tabel 5. menunjukkan bahwa rataan skor aroma pellet pakan kelinci perlakuan T0, T1 dan T2 berturut-turut adalah 4,00; 3,69 dan 3,64. Hasil analisis ragam menunjukkan bahwa adanya penambahan level rumput laut Sargassum sp. dalam pakan kelinci berpengaruh nyata $(\mathrm{P}<0,05)$ menurunkan skor aroma pellet pakan kelinci. Uji wilayah ganda Duncan menunjukkan bahwa perlakuan T0 berbeda nyata $(\mathrm{P}<0,05)$ lebih tinggi dari perlakuan T1 dan T2. Perlakuan T1 berbeda nyata $(\mathrm{P}<0,05)$ lebih rendah dari perlakuan $\mathrm{T} 0$ dan tidak berbeda nyata lebih tinggi dari perlakuan T2. Perlakuan T2 berbeda nyata $(\mathrm{P}<0,05)$ lebih rendah dari perlakuan $\mathrm{T0}$ dan tidak berbeda nyata lebih rendah dari perlakuan T1.

Penurunan aroma pellet dari aroma segar ke aroma agak amis terjadi karena bahan pakan rumput laut Sargassum $s p$. berasal dari laut sehingga akan membawa aroma amis yang didalamnya terdapat garam dari air laut yang masih terkandung di dalam bahan pakan. Pellet yang memenuhi standar aroma hanya pada perlakuan T0 yaitu tanpa menggunakan
Sargassum sp. karena beraroma segar. Menurut Utomo (2010) menyatakan bahwa aroma pellet yang baik adalah yang segar dan tidak tengik karena akan berpengaruh pada aroma kesukaan pada ternak sehingga dapat mempengaruhi konsumsi ternak. Menurut Harianto et al. (2016) menyatakan bahwa pakan yang baik memiliki bau khas yaitu berasal dari bahan pakan penyusunnya dan beraroma segar. Hasil menunjukkan bahwa perlakuan terbaik untuk aroma pellet yaitu pada perlakuan T0 yang beraroma segar karena sudah sesuai dengan standar aroma pellet.

\section{KESIMPULAN}

Berdasarkan hasil penelitian dapat disimpulkan bahwa penggunaan level rumput laut Sargassum $s p$. hingga $8 \%$ dapat menurunkan tingkat kekerasan pellet, nilai durabilitas pellet yang baik, warna coklat kehitaman, tekstur pellet semakin kasar dan aroma pellet agak berbau amis.

\section{DAFTAR PUSTAKA}

Aslamsyah, S. dan M. Y. Karim. 2012. Uji organoleptik, fisik, dan kimiawi pakan buatan untuk ikan bandeng yang disubstitusi dengan tepung cacing tanah (Lumbricus sp.). J. Akuakultur Indonesia 11(2): 124-131.

Fathia, N. 2016. Uji Sifat Fisik dan Mekanik Pakan Ikan Buatan dengan Perekat Tepung Tapioka. Fakultas Pertanian, Universitas Lampung, Bandar Lampung. (Skripsi).

Harianto, D. K., A. D. Sasanti dan M. Fitrani. 2016. Pengaruh perbedaan lama waktu penyimpanan pakan berprobiotik terhadap kualitas pakan. J. Akuakultur Rawa Indonesia 4 (2): 117-127.

Herawati, H. 2011. Potensi pengembangan produk pati tahan cerna sebagai pangan fungsional. J. Litbang Pertanian 30 (1): 31-39.

Ilmiawan, T., B. Sulistiyanto dan C. S. Utama. 2015. Pengaruh penambahan pollard fermentasi dalam pellet terhadap serat 
kasar dan kualitas fisik pellet. J. Litbang Provinsi Jawa Tengah 13 (2): 143-152.

Ismi, R. S., R. I. Pujaningsih dan S. Sumarsih. 2017. Pengaruh penambahan level molasses terhadap kualitas fisik dan organoleptik pellet pakan kambing periode penggemukan. J. Ilmiah Peternakan Terpadu 5 (3): 58-63.

Krisnan, R. dan S. P. Ginting. 2009. Penggunaan solid Ex-Decanter sebagai binder pembuatan pakan komplit berbentuk pellet. Prosiding Seminar Nasional Teknologi Peternakan dan Veteriner. Bogor, 13-14 Agustus 2009. Pusat Penelitian dan Pengembangan Peternakan, Bogor. 480-486.

Luthfiyana, N,. Nurjanah, M. Nurilmala, E. Anwar dan T. Hidayat. 2016. Rasio bubur rumput laut Eucheuma cottonii dan Sargassum $s p$. sebagai formula krim tabir surya. J. Pengolahan Hasil Perikanan Indonesia 19 (3): 183-195.

Ma'ruf, W. F., I. Ratna, N. D. Eko dan A. Ulfah. 2013. Profil rumput laut Caulerpa racemose dan Gracilaria verrucosa sebagai edible food. J. Saintek Perikanan 9 (1): 68-74.

Mas, I. K. G. Y. 2015. Analisis Statistika dalam Percobaan Satu Faktor untuk llmu Peternakan. Media Inspirasi Semesta, Semarang.

Molina, E., P. G. Redondo, R. M. Rojas, K. M. Quintero, B. Bracho and A. S. Urdanetta. 2015. Effect of diets with Amaranthus dubius mart. Ex Thell. on performance and digestibility of groeing rabbits. World Rabbit Science 23 (1): 9-18).

Mukodiningsih, S., S. P. S. Budhi, A. Agus, Haryadi dan S. J. Ohh. 2010. Effect of molasses addition level to the mixture of calf starter and corn fodder on pellet quality, rumen development and performance of Holstein-Friesian Calves in Indonesia. J. Animal Science and Technology 52 (3): 229-236.
Mulia, D. S., F. Wulandari dan H. Maryanto. 2017. Uji fisik pakan ikan yang menggunakan binder tepung gaplek. J. Riset Sains dan Teknologi 1(1): 37-44.

NRC. 1977. Nutrien Requirement of Rabbit. $2^{\text {nd }}$ revised edition. National Academy of Science, Washington D. C. p 10.

Rachmayanti, A., R. M. Sari dan A. F. Ilhamdy. 2019. Proses sakarifikasi dan fermentasi terpisah pada produksi bioetanol dari bahan baku rumput laut Sargassum sp. J. Marinade 2(1): 19-28.

Rahmana, I., D. A. Mucra dan D. Febrina. 2016. Kualitas fisik pellet ayam broiler periode akhir dengan penambahan feses ternak dan bahan perekat yang berbeda. J. Peternakan 13 (1): 33-40.

Retnani, Y., N. Hasanah, Rahmayeni dan L. Herawati. 2010. Uji sifat fisik ransum ayam broiler bentuk pellet yang ditambahkan perekat onggok melalui proses penyemprotan air. J. Agripet 10 (1): 13-18.

Ruslan dan A. Wiraningtyas. 2019. Ekstraksi zat warna dari rumput laut Sargassum sp.. J. Pendidikan Kimia dan Ilmu Kimia 2 (1): 1-10.

Satriawan, D. D., E. Kumalasari dan A. Hamzah. 2017. Sistem pakar mendiagnosa penyakit pada kelinci berbasis web. J. Script 4 (2): 148-155.

Susilawati, I., Mansyur dan R. Zamhir. 2012. Penggunaan berbagai bahan pengikat terhadap kualitas fisik dan kimia pelet hijauan makanan ternak. J. Ilmu Ternak $12(1): 47-50$.

Triwisari, D. A. 2010. Fraksinasi Polisakarida Beberapa Jenis Rumput Laut. Institut Pertanian Bogor, Bogor. (Skripsi)

Utomo, A. J. 2010. Palatabilitas serta Rasio Konsumsi Pakan dan Air Minum Kelinci Jantan Lokal Peranakan New Zealand White yang Diberi Pellet atau Silase Ransum Komplit. Institut Pertanian Bogor, Bogor. (Skripsi) 